\title{
QUALITY OF LIFE AND HEALTH STATUS IN MIDDLE-AGED PRESUMED HEALTHY SLOVENIAN FAMILY PRACTICE ATTENDEES
}

\section{KAKOVOST ŽIVLJENJA IN ZDRAVSTVENO STANJE DOMNEVNO ZDRAVIH OBISKOVALCEV AMBULANT DRUŽINSKE MEDICINE SREDNJIH LET V SLOVENIJI}

\author{
Matic TEMENT'1 , Polona SELIČ - ZUPANČIČ2
}

${ }^{1}$ University of Maribor, Faculty of Medicine, Department of Family Medicine, Taborska 8, 2000 Maribor, Slovenia ${ }^{2}$ University of Ljubljana, Faculty of Medicine, Department of Family Medicine, Poljanski nasip 58, 1000 Ljubljana, Slovenia

\author{
ABSTRACT \\ Keywords: \\ health related quality \\ of life, health status, \\ family practice, \\ middle-age, \\ physical activity, \\ depression, \\ stress, coping
}

Background: There is a gap in our knowledge of health-related quality of life (HRQoL) in a population presumed healthy, so this study aimed to assess the associations between HRQoL, demographics and clinical variables.

Methods: The participants were attendees, presumed healthy, at 40 pre-selected model family medicine practices (MFMPs), aged between 30 and 65 years and recruited during a preventive check-up in 2019. Each MFMP pragmatically invited 30 attendees to voluntarily participate. The EQ-5D questionnaire was administered as a measure of HRQoL; the independent variables were demographic characteristics, smoking, alcohol consumption, stress perception, physical activity, signs of depression, cardiovascular risk, body mass index, blood pressure values, and blood sugar and lipidogram laboratory test values. Ordinal logistic regression was used to calculate associations between self-assessed quality of life, demographics, and clinical variables, with $\mathrm{P}<0.05$ set as statistically significant.

Results: Of 986 participants, 640 (64.9\%) were women and 346 (35.1\%) men, aged $42.7 \pm 8.6$ years. The average values for the EQ-5D-3L were $0.91 \pm 0.15$. In the multivariate model, a positive association between adequate physical activity $(p=0.003)$, and a negative association between higher age $(p<0.001)$, female gender $(p=0.009)$, signs of depression $(p<0.001)$, stress $(p=0.013)$, and EQ-5D score were identified.

Conclusion: Given that physical activity was shown to be positively associated with HRQoL, it is of the utmost importance for family physicians to motivate their middle-aged patients, especially women and those with signs of depression and excessive stress, to adopt a more rigorously physically active lifestyle.

\section{IZVLEČEK}

Ključne besede: z zdravjem povezana kakovost življenja, zdravstveni status, družinska medicina, srednja leta, telesna aktivnost, depresivnost, spoprijemanje s stresom zdravstvenega varstva - novo orodje v primarni preventivi (ID L7-9414). V študijo so bili vključeni na videz zdravi
Izhodišča: Zdravstveni status ima pomemben vpliv na kakovost življenja (KŽ). Breme bolezni in njihov vpliv na $K Z ̌$ sta dobro raziskana, podatkov o KŽ pri na videz zdravi populaciji je malo. Namen te študije je bil ugotoviti, kakšna je KŽ zdravih obiskovalcev ambulant družinske medicine (ADM) v Sloveniji ter prepoznati povezavo med samoocenjeno KŽ, demografskimi podatki in določenimi kliničnimi spremenljivkami, ki se jih pogosto določa $\checkmark$ ADM. Dobljeni rezultat služi za podporo zdravstvenim delavcem na primarni ravni pri izbiranju usmerjenih intervencij za krepitev KŽ pacientov.

Metode: Raziskava je del projekta Razvoj algoritma za določanje genetskega tveganja na primarni ravni udeleženci preventivnega zdravstvenega pregleda, stari med 30 in 65 let, ki so obiskali vnaprej izbrane ADM. Vsaka od teh ADM je vključila 30 zaporednih obiskovalcev. S pomočjo multivariantne analize je bila izračunana povezava med demografskimi značilnostmi, kajenjem, uživanjem alkohola, zaznavanjem stresa, anamnezo telesne dejavnosti, kakovostjo vsakodnevne prehrane, znaki depresivnosti, tveganjem za srčno-žilne bolezni, indeksom telesne mase, krvnim tlakom, glukozo v krvi, vrednostjo maščob v serumu in Kž. Vprašalnik Eq-5D-3L je bil uporabljen kot kazalnik z zdravjem povezane KŽ. Meja $p<0,05$ je bila določena kot statistično značilna.

Rezultati: Med 986 udeleženci raziskave je bilo 650 (64,9 \%) žensk in 346 (35,1\%) moških. Povprečna starost je bila 42,7 $\pm 8,6$ (30-66) let. Povprečne vrednosti Eq-5D-3L so bile 0,91 $\pm 0,15(0,05-1,00)$. V multivariantnem modelu je bila ugotovljena pozitivna povezava med zadostno telesno dejavnostjo in vrednostjo Eq-5D-3L $(p=$ $0,003)$. Negativna povezava je bila ugotovljena med vrednostjo Eq-5D-3L in višjo starostjo $(p<0,001)$, ženskim spolom ( $p=0,009)$, znaki depresivnosti $(p<0,001)$ ter zaznavanjem stresnih obremenitev $(p=0,013)$.

Zaključek: Rezultati nakazujejo, da je z zdravjem povezana KŽ zdravih odraslih obiskovalcev ADM $v$ Sloveniji primerljiva s podatki bližnjih držav. Iz dobljenih podatkov lahko sklepamo, da je za krepitev KŽ izjemnega pomena, da referenčne sestre in zdravniki paciente motivirajo za povečanje telesne dejavnosti ter učinkovito spoprijemanje s stresom, kar velja predvsem za starejše, ženske ter tiste z znaki depresivnosti.

This article was presented at the ISCPC conference, which took place virtually on the 12th of February, 2021. The conference was organised by the Community Health Centre Ljubljana and Medical Faculty, University of Ljubljana, Slovenia.

*Corresponding author: Tel. + 38631379 707; E-mail: polona.selic@mf.uni-lj.si 


\section{INTRODUCTION}

Health-related quality of life (HRQoL) is an important measure of medical outcomes which has been shown to be associated with demographic factors and the most common mental and chronic somatic diseases (1).

Today's family doctors (FD) encounter more patients suffering from more than one chronic condition than they did in the past (2). Since a cure for such patients is often impossible, an important goal of medical practice is now to improve patients' quality of life (QoL) (3). QoL is an individual's perception of their position in life in the context of the culture and value system in which they live, related to their goals, expectations, standards and concerns $(4,5)$. It has been increasingly used as an outcome measure to evaluate patients with chronic diseases $(6,7)$. HRQoL has been shown to be suitable for use in medicine due to its focus on patients' health-related expectations. Generally, HRQoL is interpreted as the impact that health conditions and symptoms have on an individual's QoL (8); with that in mind, the components of HRQoL are physical functioning, mental health, physical pain, general health, vitality, and social functioning $(9,10)$.

As an multidimensional way of measuring patients' experience of their health, HRQoL is an important health outcome measure (11), and the concept of HRQoL has been recognised in its practical applications (12) and also as a central public health goal (13).

Disease-specific and multimorbidity-related impacts on HRQoL have already been well studied (14-16), but data about HRQoL in a population presumed healthy is scarce. In Slovenia, a study on HRQoL in family practice attendees was carried out in 2001 (17), but lacked objective information on health status. Ten years later a Slovenian study on HRQoL, which was carried out in the general population, included some self-reported data on health status, but no objective measurements such as laboratory tests (18).

Because most of the studies that have been performed so far were cross-sectional, little is known about changes in HRQoL over several years, or about any factors predicting a change in HRQoL. However, in a longitudinal, multi-centred study between 2003 and 2005, data were collected from 1118 consecutive attendees from 60 family medicine practices in Slovenia on QOL, socio-demographic factors, and the presence of mental disorders, with followups after 6 and 24 months. Retrospective information on chronic diseases was obtained from the patients' health records. In three time-sequential multiple linear regression models, data on 601 patients $(53.8 \%)$ were analysed to determine the factors associated with each component score of QoL (1), aimed at identifying those factors which predict a change in HRQoL over a longer time interval. Average QoL was seen to improve over the two-year period. Factors significantly and consistently associated with a better mental component score of QoL were social support, satisfactory circumstances in the patient's household, and absence of anxiety. Major life events in the past year and depression were shown to be risk factors for both mental and physical components, while the level of education, absence of long-term disability, and chronic pain were identified as predictors of the physical component (1). Besides condition-specific interventions for improving patients' HRQOL (19), FDs are in need of evidence-based interventions for family practice attendees presumed healthy.

The primary objective of this study was to determine the overall Health-Related Quality of Life (HRQoL) of the presumed healthy, middle-aged, Slovenian population. The results were expected to be in concordance with research findings from neighbouring countries, with a relatively high overall HRQoL score. The secondary objective was to find associations between demographic characteristics, lifestyle data, clinical variables and self-reported HRQoL. The study hypothesis was that at least some indications of a mental disease would result in lower HRQoL scores. Similar results were expected in participants of greater age, higher body weight and those with a history of alcohol abuse.

\section{METHODS}

\subsection{Participants and procedure}

This study is part of the research project Development of an Algorithm for Determining Genetic Risk at the Primary Healthcare Level: a New Tool for Primary Prevention (ID L79414) (20). The study's participants were people presumed healthy, aged 30 to 65 years, who came to 40 pre-selected model family medicine practices (MFMP) during the year 2019. AMFMP is defined as a team consisting of a FD, a practice nurse and a registered nurse. The MFMPs were selected through pragmatic sampling and participated voluntarily; however, their locations are representative of the specifics of urban and rural living environments, as several were in the capital and many in small towns across the country. Before conducting the study, the MFMPs were familiarised with the methodology and implementation of the dataset by attending a short workshop. Every MFMP pragmatically invited 30 attendees during a preventive examination and all participated voluntarily. Informed consent was provided by the patient's signature to a statement. The exclusion criteria were: age less than 30 or over 65 , and inability to participate in the study due to blindness, psycho-organic impairment or intellectual disability.

\subsection{Instruments and measures}

As part of the MFMP protocol, the following data were collected from the participants: age, gender, nutritional history, history of physical activity, and smoking habits. 
Alcohol consumption, perception of stress, signs of depression, social health determinants, body mass index, blood pressure values, laboratory test values (blood sugar, complete serum cholesterol, serum LDL, serum HDL, serum triglycerides), and cardiovascular risk based on Framingham risk scores (20) were also determined.

The patients' nutritional history was assessed using a 4-part questionnaire about a number of daily meals, vegetable and fat consumption, and use of salt. The points were awarded according to daily intake of 3-5 meals, regular breakfast, vegetables, fruit consumption, use of dairy products and milk with lower fat content, eating little or no processed meat products, not adding more salt to prepared food, using an appropriate type of fat for cooking, and using an appropriate type of bread spread. Nutrition was marked as appropriate with $\geq 14$, satisfactory with 9 to 13, and inappropriate with $\leq 8$ points appointed.

A participant was considered to be "borderline" physically active when they were engaged in high-intensity physical activity twice per week, or in moderate-intensity physical activity 2-4 times per week. If a participant was less physically active than that, their activity was marked as "inadequate", while if a participant was more physically active than that, their activity was marked as "adequate".

Stress perception risk was derived from participants' selfassessed stress load (Not feeling under stress at all - Feeling under stress every day) and ability to cope (Successful coping - Not coping at all), which both had 1-5 points and the sum 2-10; when $\geq 8$, the high risk was appointed.

A two-question scale was used to identify signs of depression (how often the participant felt disinterested or dissatisfied with their daily activities in the past two weeks and how often they felt gloomy, depressed or desperate over the same period of time) each with up to 3 points and the answers weighted according to frequency (Never - Almost every day); the sum was up to 10 and the threshold $\geq 2$ points.

As a measure of HRQoL, the EQ-5D-3L utility index was used $(21,22)$. The EQ-5D-3L questionnaire is a health status measure that focuses on five dimensions of health: mobility MO, self-care SC, usual activities UA, pain/discomfort PD and anxiety/depression $A D$. In each dimension, there are three response categories representing no problems-1, moderate problems-2 (some problems in MO, SC and UA; moderate PD and $A D$ ); severe problems -3 (unable MO, SC and $U A$, extreme PD and $A D$ ). Respondents are asked to indicate for each dimension the level of problem that best describes their current health status. The responses (1, 2 or 3) for the five dimensions can be combined into a five-digit number that describes the respondent's health state (e.g. no problem in any of the five dimensions can be described as 11111; some problems in Mobility but no problem in the other four dimensions is presented as
21111). The descriptive system can define 243 different health states. To each health state, an EQ-5D-3L index score can be attached according to a particular set of preference weights, also called a value set (23). Indices of health states with moderate and severe levels of isolated problems in each dimension (e.g. 21111, 31111, etc.), as well as the combinations of moderate and severe problems (21122, 22222, 32233, 33333) against full health (11111), were used as suggested by Prevolnik Rupel et al. (22).

For assessment of alcohol consumption, the Slovenian version of the AUDIT-C was administered (24).

\subsection{Data analysis}

The data analysis for the whole research project has already been described elsewhere (7). For this study, multivariate modelling was used to calculate the associations between factors with regard to demographics, social health determinants, smoking, alcohol consumption, perception of stress, history of physical activity, and signs of depression. Cardiovascular risk, body mass index, blood pressure values, and laboratory test values for fasting blood sugar and lipid levels were also included in ordinal logistic regression.

For the statistical analysis, IBM SPSS 25 (IBM Corp., Armonk, NY) software was used, and $\mathrm{p}<0.05$ was set as statistically significant.

\section{RESULTS}

A total of 986 participants completed the check-up. Almost two thirds $(64.9 \% ; n=649)$ were women, aged $42.7 \pm 8.6$ (30-66) years, with MEQ-5D-3L $0.91 \pm 0.15$. The range of the EQ-5D-3L utility index was between -0.498 and 1.0.

The vast majority of the participants (95.8\%) did not show any signs of depression. Their physical activity was inadequate in $7.6 \%$ cases and adequate or borderline adequate in $92.4 \%$ cases, and $62 \%$ had their nutritional habits marked as inappropriate. Only 5.0\% abstained from alcohol; $90.1 \%$ were low-risk and $4.1 \%$ high-risk drinkers. Of the total, $86.4 \%$ were non-smokers; $63.7 \%$ had a Framingham cardiovascular risk score of less than $5 \%$, and $4.3 \%$ had more than a $20-40 \%$ risk. The perception of stress was of low risk in the majority (96.6\%). High blood pressure was measured in $12.2 \%$, high levels of blood glucose in $0.6 \%$, serum cholesterol in $22.8 \%$, serum triglyceride in $10.3 \%$, and LDL in $64.6 \%$ of the participants, respectively, and low serum HDL in $11.7 \%$ (Table 1 ). 
Table 1. Clinical characteristics of participants.

\begin{tabular}{|c|c|c|}
\hline Variable & $\mathrm{n}$ & $\%$ \\
\hline \multicolumn{3}{|l|}{ Signs of depression } \\
\hline No & 945 & 95.8 \\
\hline Yes & 41 & 4.2 \\
\hline \multicolumn{3}{|l|}{ Physical activity } \\
\hline Inadequate & 75 & 7.6 \\
\hline Adequate/borderline & 911 & 92.4 \\
\hline \multicolumn{3}{|l|}{ Alcohol consumption status } \\
\hline Abstinent & 49 & 5.0 \\
\hline Non-risky drinking & 897 & 91.0 \\
\hline Risky drinking & 40 & 4.1 \\
\hline \multicolumn{3}{|l|}{ Smoking } \\
\hline No & 852 & 86.4 \\
\hline Yes & 134 & 13.6 \\
\hline \multicolumn{3}{|l|}{ Framingham cardiovascular risk score } \\
\hline$<5 \%$ & 628 & 63.7 \\
\hline $5-10 \%$ & 203 & 20.6 \\
\hline $10-20 \%$ & 113 & 11.5 \\
\hline $20-40 \%$ & 42 & 4.3 \\
\hline \multicolumn{3}{|l|}{ Nutrition } \\
\hline Inappropriate & 611 & 62.0 \\
\hline Satisfactory & 303 & 30.7 \\
\hline Appropriate & 72 & 7.3 \\
\hline \multicolumn{3}{|l|}{ Perception of stress } \\
\hline Low risk & 952 & 96.6 \\
\hline High risk & 34 & 3.4 \\
\hline \multicolumn{3}{|l|}{ BMI (kg/m2) } \\
\hline$\leq 25$ & 482 & 48.9 \\
\hline $25-9.9$ & 368 & 37.3 \\
\hline$\geq 30$ & 136 & 13.8 \\
\hline $\begin{array}{l}\text { High blood pressure } \\
\left(>140 \mathrm{mmHg}_{\text {systolic }} / 90 \mathrm{mmHg}_{\text {diastolic }}\right)\end{array}$ & 120 & 12.2 \\
\hline High blood glucose (>7 mmol/L) & 6 & 0.6 \\
\hline High serum cholesterol ( $>5 \mathrm{mmol} / \mathrm{L})$ & 225 & 22.8 \\
\hline High serum triglycerides ( $>2 \mathrm{mmol} / \mathrm{L}$ ) & 102 & 10.3 \\
\hline $\begin{array}{l}\text { Low serum HDL } \\
\left(<1.2 \mathrm{mmol} / \mathrm{L}_{\text {men }} ;<1.0 \mathrm{mmol} / \mathrm{L}_{\text {women }}\right)\end{array}$ & 115 & 11.7 \\
\hline High serum LDL (>3 mmol/L) & 637 & 64.6 \\
\hline
\end{tabular}

Biochemical and other measures are presented in Table 2.
Table 2. Biochemical and other measures.

\begin{tabular}{lcccc}
\hline Variable & Mean & $\begin{array}{c}\text { Standard } \\
\text { deviation }\end{array}$ & $\min$ & $\max$ \\
\hline BMI $\left(\mathrm{kg} / \mathrm{m}^{2}\right)$ & 25.7 & 4.9 & 16.5 & 65.6 \\
Systolic blood pressure (mmHg) & 122.7 & 13.9 & 85 & 176 \\
Diastolic blood pressure (mmHg) & 78.4 & 9.7 & 50 & 132 \\
Blood glucose (mmol/L) & 5.1 & 0.6 & 3.2 & 10.0 \\
Serum cholesterol (mmol/L) & 5.3 & 1.0 & 2.0 & 10.8 \\
Serum triglyceride (mmol/L) & 1.3 & 0.8 & 0.2 & 7.8 \\
Serum HDL (mmol/L) & 1.6 & 0.4 & 0.4 & 5.0 \\
Serum LDL (mmol/L) & 3.3 & 0.9 & 0.6 & 7.6 \\
\hline
\end{tabular}

In the multivariate model, adequate physical activity was associated with higher EQ-5D-3L utility index $(p=0.003)$. Lower EQ-5D-3L utility index was obtained in participants who were older $(p<0.001)$, women $(p=0.009)$, had signs of depression $(p<0.001)$ or had high-risk perception of stress $(p=0.013)$ (Table 3).

Table 3. Associations between demographic values, health status and EQ-5D utility index.

\begin{tabular}{|c|c|c|c|c|}
\hline \multirow[b]{2}{*}{ Age } & \multirow{2}{*}{$\begin{array}{c}\text { Odds } \\
\text { ratio }\end{array}$} & \multicolumn{2}{|c|}{$\begin{array}{c}95 \% \\
\text { Confidence } \\
\text { Interval }\end{array}$} & \multirow{2}{*}{$\begin{array}{c}P \\
<0.001\end{array}$} \\
\hline & & 0.92 & 0.96 & \\
\hline \multicolumn{5}{|l|}{ Gender } \\
\hline Male & 1.00 & & & \\
\hline Female & 0.64 & 0.45 & 0.89 & 0.009 \\
\hline \multicolumn{5}{|l|}{ Signs of depression } \\
\hline Yes & 1.00 & & & \\
\hline No & 0.11 & 0.06 & 0.19 & $<0.001$ \\
\hline \multicolumn{5}{|l|}{ Physical activity } \\
\hline Inadequate & 1.00 & & & \\
\hline Adequate/borderline & 2.08 & 1.29 & 3.35 & 0.003 \\
\hline \multicolumn{5}{|l|}{ Alcohol drinking status } \\
\hline Abstinent & 1.00 & & & \\
\hline Non-risky drinking & 0.79 & 0.41 & 1.52 & 0.474 \\
\hline Risky drinking & 0.75 & 0.29 & 1.96 & 0.558 \\
\hline \multicolumn{5}{|l|}{ Smoking } \\
\hline No & 1.00 & & & \\
\hline Yes & 1.01 & 0.67 & 1.54 & 0.948 \\
\hline \multicolumn{5}{|l|}{ Nutrition } \\
\hline Inappropriate & 1.00 & & & \\
\hline Satisfactory & 1.34 & 0.98 & 1.82 & 0.067 \\
\hline Appropriate & 1.34 & 0.74 & 2.40 & 0.332 \\
\hline \multicolumn{5}{|l|}{ Perception of stress } \\
\hline Low risk & 1.00 & & & \\
\hline High risk & 0.43 & 0.22 & 0.84 & 0.013 \\
\hline
\end{tabular}




\begin{tabular}{|c|c|c|c|c|}
\hline & $\begin{array}{l}\text { Odds } \\
\text { ratio }\end{array}$ & \multicolumn{2}{|c|}{$\begin{array}{c}95 \% \\
\text { Confidence } \\
\text { Interval }\end{array}$} & $P$ \\
\hline \multicolumn{5}{|c|}{$\begin{array}{l}\text { Framingham cardiovascular } \\
\text { risk score }\end{array}$} \\
\hline$<5 \%$ & 1.00 & & & \\
\hline $5-10 \%$ & 0.80 & 0.55 & 1.18 & 0.260 \\
\hline $10-20 \%$ & 1.18 & 0.68 & 2.07 & 0.553 \\
\hline $20-40 \%$ & 0.94 & 0.45 & 1.97 & 0.870 \\
\hline \multicolumn{5}{|c|}{ BMI (kg/m2) } \\
\hline$\geq 25$ & 1.00 & & & \\
\hline $25-29.9$ & 0.78 & 0.57 & 1.08 & 0.139 \\
\hline$\leq 30$ & 0.66 & 0.43 & 1.02 & 0.058 \\
\hline \multicolumn{5}{|c|}{$\begin{array}{l}\text { High blood pressure (>140 } \\
\mathrm{mmHg}_{\text {systolic }} / 90 \mathrm{mmHg}_{\text {diastolic }} \text { ) }\end{array}$} \\
\hline No & 1.00 & & & \\
\hline Yes & 0.78 & 0.51 & 1.20 & 0.257 \\
\hline \multicolumn{5}{|c|}{ High blood glucose (>7 mmol/L) } \\
\hline No & 1.00 & & & \\
\hline Yes & 0.47 & 0.10 & 2.25 & 0.343 \\
\hline \multicolumn{5}{|c|}{$\begin{array}{l}\text { High serum cholesterol } \\
(>5 \mathrm{mmol} / \mathrm{L})\end{array}$} \\
\hline No & 1.00 & & & \\
\hline Yes & 1.26 & 0.86 & 1.84 & 0.229 \\
\hline \multicolumn{5}{|c|}{$\begin{array}{l}\text { High serum triglycerides } \\
\text { (>2 } \mathrm{mmol} / \mathrm{L})\end{array}$} \\
\hline No & 1.00 & & & \\
\hline Yes & 0.98 & 0.60 & 1.62 & 0.943 \\
\hline \multicolumn{5}{|c|}{$\begin{array}{l}\text { Low serum HDL }(<1.2 \mathrm{mmol} / \\
\left.\mathrm{L}_{\text {men }} ;<1.0 \mathrm{mmol} / \mathrm{L}_{\text {women }}\right)\end{array}$} \\
\hline No & 1.00 & & & \\
\hline Yes & 0.95 & 0.57 & 1.59 & 0.843 \\
\hline \multicolumn{5}{|c|}{ High serum LDL (>3 $\mathrm{mmol} / \mathrm{L})$} \\
\hline No & 1.00 & & & \\
\hline Yes & 0.97 & 0.70 & 1.34 & 0.840 \\
\hline
\end{tabular}

Nagelkerke $R^{2}=0.170$

\section{DISCUSSION}

This study firstly aimed at assessing the overall QOL of the presumably healthy, middle-aged Slovenian population, and secondly at identifying the associations between demographic characteristics, lifestyle data, clinical variables and self-reported HRQoL. The average HRQoL (the mean EQ-5D-3L utility index) was very similar to the scores of the general population of comparable countries $(0.91$ for Slovenia, 0.915 for Italy, 0.915 for Germany) $(25,26)$; older age was associated with lower HRQoL (Table 3), similarly to several other studies (2629); and the same was true for perception of stress or signs of depression $(27,30,31)$. Previous research in
Slovenia focused on the correlation between the quality of life, chronic diseases and several other characteristics of patients in family medicine, and found the physical health score to be negatively associated with higher age, depression and a number of chronic somatic diseases (32). In Slovenian research, HRQoL has been shown to improve significantly in more highly educated people with good social support and satisfactory circumstances in their household, the absence of major life events in the past 12 months, good self-assessment of health, and the absence of depression, anxiety disorders or chronic pain (1); the results of this longitudinal research project expanded the previous evidence from cross-sectional population-based and clinical studies that investigated the association of several variables with HRQoL. A small number of studies have found a correlation between female gender and lower HRQoL $(26,29,33)$, but others did not find such associations (18). The results of our study (Table 3) matched a positive correlation between physical activity and higher HRQoL with previous studies (28) (34), but contrary to our hypothesis, alcohol consumption did not lower HRQoL scores. As Černe et al. concluded in their review (35), the association between alcohol consumption and QoL in Slovenia has not yet been well studied; however, the results from other countries show a clear negative correlation between alcohol consumption and HRQoL (36). The explanation for our findings could lie in the inability of the EQ-5D to detect lower psychological well-being in alcohol-dependent subjects without signs of anxiety and/or depression, as Günther et al. observed in their study (37).

The population norms presented by Prevolnik Rupel et al. (38) were also very informative in interpreting this study's results, since participants were "presumed healthy" and comparisons with various patient groups would not make a lot of sense. In our study, blood pressure, fasting glucose and lipid levels were not associated with statistically significant variability in EQ-5D-3L utility index (Table 3). Studies on patients with a diagnosis of hypertension found a lower HRQoL in people with a confirmed diagnosis than in those without a diagnosis of hypertension $(39,40)$, but this is not concordant with our study's results, which showed that even patients with higher blood pressure values did not have statistically significant lower EQ-5D-3L utility index scores. However, in a previous study carried out in Slovenia, Selič et al. (41) reported the burden of somatic co-morbidity to be smaller than the impact of psychosocial determinants when identifying patterns of physical co-morbidity and factors associated with the onset of depression. Psychosocial determinants, i.e. the feeling of safety at home and the absence of problems in intimate relationships, were interpreted as a protective factor (41). On the other hand, in a longitudinal study of the predictors of HRQoL in patients with arterial 
hypertension, Maatouk et al. reported that most somatic diseases were associated with a lower HRQoL after five years (42). In another Slovenian study, Černe et al. (1) reported that neither the impact of the severity of chronic somatic disease, nor the time since diagnosis could be proven, although these are known to have a particular impact on HRQoL according to patients' adaptation to disease, as stated by Schwartz and Sprangers in their response shift theory (43). We embrace the explanation that individuals experiencing a change in their health status may also change their appraisals, internal standards and values with regard to HRQoL, and will try to research possible associations further.

On the other hand, it could be speculated that the results of this study (Table 3 ) could be due to a shorter duration of the negative effects of high blood pressure. A similar explanation could be used to explain lower HRQoL scores in patients with dyslipidemia (44). In people with diabetes mellitus, the results from previous studies are not so univocal, as Jain et al. found no degradation of HRQoL scores in patients with the diagnosis (16), while Lu et al. found significantly lower scores in these patients (45). Again, we can assume that this study's participants had mostly not had diabetes for an extended period of time, which would result in complications and degrade the HRQoL, as has been studied before (46).

\subsection{Strengths and limitations to the study}

With regard to limitations, it might be worth mentioning that the average participant in the study was middle-aged, with no apparent health deteriorations; yet the simple fact that the patient was included in this study could have ensured that they had the impression they would be better taken care of. As this would have introduced an additional variable, and would have interfered with the real-life approach of the study, the participating healthcare provider did not receive any specific additional education about HRQoL and its dimensions. However, the registered nurses collecting the data were aware of the patients' voluntary participation in the study, so results could be skewed by the Hawthorne effect, or a change in normal behaviour when individuals are aware they are being observed.

Secondly, to gain better insight and further this research, the EQ-5D-3L utility index could have been split into five domains, i.e. mobility, self-care, usual activities, pain/ discomfort and anxiety, which some foreign authors have done (47). It would have given the opportunity to test associations with health status and the specific domains of the measures of QoL.

Another addition to the information about HRQoL would have been the use of the EQ VAS score as an additional measure of an individual's current self-reported overall health.
Finally, the use of the EQ-5D-5L instead of the EQ-5D-3L could have improved the sensitivity and precision of this study's results, as stated by Janssen et al. (48).

The authors believe it is important to emphasize the confirmatory value of this study's results due to the concordance with previous research in Slovenia. We succeeded in confirming that the absence of depression and stressful life events in the previous year acted as the most important predictors of HRQoL as a whole (1), given that the study's results found that signs of depression $(p<0.001)$ and high risk perception of stress $(p=0.014)$ (Table 3) were associated with lower HRQoL scores.

The study's results may also act as a general impression of the HRQoL of family practice attendees, and confirmed the finding of Petek et al. (28) that patients who are not "really sick" should be consistently encouraged to improve or keep a healthy lifestyle, particularly in physical activity, in order to improve HRQoL.

The very strength of this study is the sample size, which provided a solid ground for another important finding that people "presumed healthy" are not necessarily healthy and need targeted intervention(s). Bearing this in mind when focusing on this group of family practice attendees could save many resources in the healthcare system and society at large.

\section{CONCLUSIONS}

This study showed that even presumably healthy family practice attendees may have a lower HRQoL due to certain demographic and/or clinical characteristics. This is an important finding for preventive medicine, and warns that targeted interventions may also be necessary for people without known diseases.

If we were to improve the quality of life of people presumed healthy, one would need to turn towards the determinants that were found to be associated with lower HRQoL values. Dealing with stress, improving physical activity and addressing the signs of depression should be some of the main topics at preventive check-ups in family care practices. Although FDs are not able to control stressful life events affecting their patients, they can explore patients' coping mechanisms, and provide information about active, rather than passive, coping strategies.

\section{CONFLICTS OF INTEREST}

The authors declare that no conflict of interest exists. 


\section{FUNDING}

The research project Developing an algorithm for determining genetic risk at the primary healthcare level - a new tool for primary prevention, ID L7-9414 was financially supported by the Slovenian Research Agency.

\section{ETHICAL APPROVAL}

The National Medical Ethics Committee at the Ministry of Health from the Republic of Slovenia (No. 0120544/2016/3) approved the study.

\section{REFERENCES}

1. Černe A, Švab I, Kersnik J, Selič P. Did past economic prosperity affect the health related quality of life predictors? A longitudinal study on a representative sample of Slovenian family medicine patients. BMC Public Health. 2013;13:1160. doi: 10.1186/1471-2458-13-1160.

2. Alonso J, Ferrer M, Gandek B, Ware JE, Jr., Aaronson NK, Mosconi P, et al. Health-related quality of life associated with chronic conditions in eight countries: results from the International Quality of Life Assessment (IQOLA) project. Qual Life Res. 2004;13(2):283-98. doi: 10.1023/b:qure.0000018472.46236.05.

3. Coons SJ, Rao S, Keininger DL, Hays RD. A comparative review of generic quality-of-life instruments. Pharmacoeconomics. 2000;17(1):13-35. doi: 10.2165/00019053-200017010-00002.

4. The Whogol G. The World Health Organization Quality of Life Assessment (WHOQOL): development and general psychometric properties. Soc Sci Med. 1998;46(12):1569-85. doi: 10.1016/s02779536(98)00009-4.

5. Farquhar M. Definitions of quality of life: a taxonomy. J Adv Nurs. 1995;22(3):502-8. doi: 10.1046/j.1365-2648.1995.22030502.x.

6. Howes CJ, Reid MC, Brandt C, Ruo B, Yerkey MW, Prasad B, et al. Exercise tolerance and quality of life in elderly patients with chronic atrial fibrillation. J Cardiovasc Pharmacol Ther. 2001;6(1):23-9. doi: 10.1177/107424840100600103.

7. Xuan J, Kirchdoerfer LJ, Boyer JG, Norwood GJ. Effects of comorbidity on health-related quality-of-life scores: an analysis of clinical trial data. Clin Ther. 1999;21(2):383-403. doi: 10.1016/s01492918(00)88295-8.

8. Prutkin JM, Feinstein AR. Quality-of-life measurements: origin and pathogenesis. Yale J Biol Med. 2002;75(2):79-93.

9. Testa MA, Simonson DC. Assessment of quality-of-life outcomes. N Engl J Med. 1996;334(13):835-40. doi: 10.1056/nejm199603283341306.

10. Wilson IB, Cleary PD. Linking clinical variables with health-related quality of life: a conceptual model of patient outcomes. JAMA. 1995;273(1):59-65.

11. Kaplan RM. The significance of quality of life in health care. Qual Life Res. 2003;12(Suppl 1):3-16. doi: 10.1023/a:1023547632545.

12. Quinten C, Coens C, Mauer M, Comte S, Sprangers MAG, Cleeland C, et al. Baseline quality of life as a prognostic indicator of survival: a meta-analysis of individual patient data from EORTC clinical trials. Lancet Oncol. 2009;10(9):865-71. doi: 10.1016/s1470-2045(09)70200-1.

13. CDC. HRQOL Concepts 2018. Accessed October 5th, 2020 at: https:// www.cdc.gov/hrqol/concept.htm .

14. Fortin M, Lapointe L, Hudon C, Vanasse A, Ntetu AL, Maltais D. Multimorbidity and quality of life in primary care: a systematic review. Health Qual Life Outcomes. 2004;2:51. doi: 10.1186/1477-7525-2-51.
15. Souza AC, Borges JW, Moreira TM. Quality of life and treatment adherence in hypertensive patients: systematic review with meta-analysis. Rev Saude Publica. 2016;50:71. doi: 10.1590/S15188787.2016050006415.

16. Jain V, Shivkumar S, Gupta O. Health-related quality of life (hr-qol) in patients with type 2 diabetes mellitus. N Am J Med Sci. 2014;6(2):96101. doi: $10.4103 / 1947-2714.127752$.

17. Kersnik J, Vodopivec-Jamšek V. Health status of family practice patients in Slovenia. Zdrav Vestn. 2001;70(4):203-5.

18. Klemenc-Ketiš Z, Smogavec M, Softič N, Kersnik J. Health-related quality of life: a population based study from Slovenia. Cent Eur J Publ Heal. 2011;19(1):7-12. doi: 10.21101/cejph.a3636.

19. Ivetić $V$, Pašić K, Selič $P$. The effect of an educational intervention in family physicians on self-rated quality of life in patients with medically unexplained symptoms. Zdr Varst. 2017;56(2):91-8. doi: 10.1515/sjph2017-0012.

20. Selič P, Klemenc-Ketiš Z, Zelko E, Kravos A, Rifel J, Makivić I, et al. Development of an algorithm for determining genetic risk at the primary healthcare level - a new tool for primary prevention: a study protocol. Zdr Varst. 2020;59(1):27-32. doi: 10.2478/sjph-2020-0004.

21. Rupel V, Ogorevc M. The EQ-5D health states value set for Slovenia. Zdr Varst. 2012;51(2):463-71. doi: 10.2478/v10152-012-0015-y.

22. Prevolnik Rupel V, Srakar A, Rand K. Valuation of EQ-5D-3l health states in Slovenia: VAS based and TTO based value sets. Zdr Varst. 2020;59(1):8-17. doi: 10.2478/sjph-2020-0002.

23. Zrubka Z, Beretzky Z, Hermann Z, Brodszky V, Gulácsi L, Rencz F, et al. A comparison of European, Polish, Slovenian and British EQ-5D$3 \mathrm{~L}$ value sets using a Hungarian sample of 18 chronic diseases. Eur J Health Econ. 2019;20(1):119-32. doi: 10.1007/s10198-019-01069-8.

24. Kolšek M, Poplas Susič T, Kersnik J. Slovenian adaptation of the original AUDIT-C questionnaire. Subst Use Misuse. 2013;48(8):581-9. doi: $10.3109 / 10826084.2013 .793354$.

25. Scalone. L, Cortesi. PA, Ciampichini. R, Cesana. G, Mantovani LG. Health Related Quality of Life norm data of the general population in Italy: results using the EQ-5D-3L and EQ-5D-5L instruments. Epidemiol Biostat Public Healt. 2015;12(3). doi: 10.2427/11457.

26. Hinz A, Kohlmann T, Stobel-Richter Y, Zenger M, Brahler E. The quality of life questionnaire EQ-5D-5L: psychometric properties and normative values for the general German population. Qual Life Res. 2014;23(2):443-7. doi: 10.1007/s11136-013-0498-2.

27. Wang HM, Beyer M, Gensichen J, Gerlach FM. Health-related quality of life among general practice patients with differing chronic diseases in Germany: a cross sectional survey. BMC Public Health. 2008;8:246. doi: 10.1186/1471-2458-8-246.

28. Petek D, Petek-Šter M, Tušek-Bunc K. Health behavior and healthrelated quality of life in patients with a high risk of cardiovascular disease. Zdr Varst. 2018;57(1):39-46. doi: 10.2478/sjph-2018-0006.

29. Konig $\mathrm{HH}$, Bernert $\mathrm{S}$, Angermeyer MC, Matschinger $\mathrm{H}$, Martinez $M$, Vilagut $G$, et al. Comparison of population health status in six European countries: results of a representative survey using the EQ-5D questionnaire. Med Care. 2009;47(2):255-61. doi: 10.1097/ MLR.0b013e318184759e.

30. Klemenc-Ketiš Z, Kersnik J, Eder K, Colarič D. Factors associated with health-related quality of life among university students. Srp Arh Celok Lek. 2011;139(3-4):197-202. doi: 10.2298/sarh1104197k.

31. Račić M, Todorović R, Ivković N, Masić S, Joksimović B, Kulić M. SelfPerceived stress in relation to anxiety, depression and health-related quality of life among health professions students: a cross-sectional study from Bosnia and Herzegovina. Zdr Varst. 2017;56(4):251-9. doi: 10.1515/sjph-2017-0034.

32. Černe A, Rifel J, Rotar-Pavlič D, Švab I, Selič P, Kersnik J. Quality of life in patients with depression, panic syndrome, other anxiety syndrome, alcoholism and chronic somatic diseases: a longitudinal study in Slovenian primary care patients. Wien Klin Wochenschr. 2013;125(12):1-7. doi: 10.1007/s00508-012-0278-y. 
33. Azpiazu Garrido M, Cruz Jentoft A, Villagrasa Ferrer JR, Abanades Herranz JC, García Marín N, Álvarez de Mon Rego C. Quality of life in non-institutionalized persons older than 65 years in two health care districts in Madrid. Atención Primaria. 2003;31(5):285-92. doi: 10.1016/S0212-6567(03)79180-X.

34. Mitchell T, Barlow CE. Review of the role of exercise in improving quality of life in healthy individuals and in those with chronic diseases. Curr Sports Med Rep. 2011;10(4):211-6. doi: 10.1249/ JSR.0b013e318223cc9e.

35. Černe A, Zaletel-Kragelj L, Selič P. Quality of life and alcohol consumption: a review of the literature. Zdr Varst. 2012;51(2):147-54. doi: 10.2478/v10152-012-0017-9.

36. Saatcioglu O, Yapici A, Cakmak D. Quality of life, depression and anxiety in alcohol dependence. Drug Alcohol Rev. 2008;27(1):83-90. doi: 10.1080/09595230701711140.

37. Gunther O, Roick C, Angermeyer MC, Konig HH. The EQ-5D in alcohol dependent patients: relationships among health-related quality of life, psychopathology and social functioning. Drug Alcohol Depend. 2007;86(2-3):253-64. doi: 10.1016/j.drugalcdep.2006.07.001.

38. Prevolnik Rupel V, Slabe-Erker R, Divjak M. Comparing quality of life of general population and orthopedic patients in Slovenia. Value Health Reg Issues. 2020;22:93-8. doi: 10.1016/j.vhri.2020.07.575

39. Zhang L, Guo X, Zhang J, Chen X, Zhou C, Ge D, et al. Healthrelated quality of life among adults with and without hypertension: a population-based survey using EQ-5D in Shandong, China. Sci Rep. 2017;7(1):14960. doi: 10.1038/s41598-017-15083-4.

40. Carvalho MV, Siqueira LB, Sousa AL, Jardim PC. The influence of hypertension on quality of life. Arq Bras Cardiol. 2013;100(2):164-74. doi: 10.5935/abc.20130030.

41. Selič P, Švab I, Rifel J, Pavlič DR, Černe A, King M, et al. The pattern of physical comorbidity and the psychosocial determinants of depression: a prospective cohort study on a representative sample of family practice attendees in Slovenia. Ment Health Fam Med. 2011;8(3):147-55.

42. Maatouk I, Wild B, Herzog W, Wesche D, Schellberg D, Schottker B, et al. Longitudinal predictors of health-related quality of life in middleaged and older adults with hypertension: results of a populationbased study. J Hypertens. 2012;30(7):1364-72. doi: 10.1097/ HJH.0b013e328353d81b.

43. Schwartz CE, Sprangers MA. Methodological approaches for assessing response shift in longitudinal health-related quality-of-life research. Soc Sci Med. 1999;48(11):1531-48. doi: 10.1016/s0277-9536(99)00047-7.

44. Farhat A, Al-Hajje A, Rachidi S, Zein S, Zeid MB, Salameh P, et al. Risk factors and quality of life of dyslipidemic patients in Lebanon: a cross-sectional study. J Epidemiol Glob Health. 2016;6(4):315-23. doi: 10.1016/j.jegh.2016.10.001.

45. Lu Y, Wang N, Chen Y, Nie X, Li Q, Han B, et al. Health-related quality of life in type-2 diabetes patients: a cross-sectional study in East China. BMC Endocr Disord. 2017;17(1):38. doi: 10.1186/s12902-0170187-1.

46. Solli O, Stavem K, Kristiansen IS. Health-related quality of life in diabetes: the associations of complications with EQ-5D scores. Health Qual Life Outcomes. 2010;8:18. doi: 10.1186/1477-7525-8-18.

47. Mantovani LSPACRCGCLG. Health Related Quality of Life norm data of the general population in Italy: results using the EQ-5D-3L and EQ5D-5L instruments. Epidemiol Biostat Public Healt. 2015;12(3). doi: $10.2427 / 11457$.

48. Janssen MF, Bonsel GJ, Luo N. Is EQ-5D-5L better than EQ-5D-3L? A head-to-head comparison of descriptive systems and value sets from seven countries. Pharmacoeconomics. 2018;36(6):675-97. doi: 10.1007/s40273-018-0623-8. 